\title{
POLITICAL PARALLELISM AND THE CASE OF WOMEN IN MANAGEMENT POSITIONS IN PUBLIC MEDIA IN POLAND. AN ETHNOGRAPHIC STUDY
}

\author{
AUTHOR: GOBER, Greta \\ Guest Researcher-Centre for Gender Research, University of Oslo-Norway \\ greta.gober@stk.uio.no
}

\begin{abstract}
In this research, I analyze the collective and historical processes, which create the necessary conditions for the practice of gender discrimination to persist in one of the biggest public media intuitions in Poland, namely in the Polish Television (TVP). Through extensive ethnographic research and in-depth interviews, I documented how an oppressive organizational structure, first created during communism and today maintained through political parallelism (Dobek Ostrowska, 2011), became part of TVP's organizational culture. This culture has significant consequences for women's career prospects, as top

power positions in public media in Poland remain associated with politics and masculinity. Herein, I first examine the oppressive organizational structure of TVP, as experienced by its employees; and next I argue that the resulting organizational culture, imposes unequal work demands on women in the organization and leads, even the female senior managers in TVP, to engage in defending the status quo by resisting women who violate the existing gender order by reaching for the "forbidden" top positions in the organization (Rudman et al., 2012).
\end{abstract}

\section{Introduction}

"There are areas in the organization where men should be allowed to dominate. Because the can, because this is how they have organized this world, to be able to withdraw and forget about God's world."

(Celestyna, female senior manager in public television in Poland).

In this research I analyze the collective and historical processes, which create the necessary conditions for the practice of gender discrimination to persist in one of the biggest public media intuitions in Poland, namely in the Polish Television (TVP). Through extensive ethnographic research and in-depth interviews, I documented how an oppressive organizational structure, first created during communism and today maintained through political parallelism, became part of TVP's organizational culture. This culture has significant consequences for women's career prospects, as top power positions in public media in Poland remain associated with politics and masculinity (as can be seen in the opening quote).

Women's under-representation in top management positions and within the boards of media organizations around the world has been studied in the last few decades. The first global study to critically look at media organizations through gender perspective was commissioned by UNESCO and undertaken by Margaret Gallagher in 1995. Since then, many investigations have been conducted around the world (see for example: Ammu, 2005; Harrison et al., 2008; Mishra et al., 2008; North, 2009; Made \& Lowe, 2010). Most recently the International Women's Media Foundation published "The Global Report on the Status of Women in the News Media" (Byerly, 2011) and the European Institute for Gender Equality the "Review of the implementation of the Beijing Platform for Action in the EU 
Member States: Women and the Media" (EIGE, 2013). Findings point to individual, structural and societal reasons for why hierarchical and vertical gender segregation in the media industry persists around the world. Individual level explanations draw attention to sex role stereotyping, prejudice and discrimination as primary reasons for male privilege in the media. Organizational level explanations point to male-biased workplace structures and cultures, reflected amongst others in obscured recruitment processes, the gender pay gap, sexual harassment; and societal-level explanations cover broader social, political and economic contexts in which media organizations function, for example looking at issue of media ownership (Carter et al., 1998; de Bruin \& Ross, 2004; Ross \& Byerly, 2004).

In international studies, Poland in regards to women's situation in the media industry, is not doing either exceptionally bad or good, as compared to other EU countries (EIGE, 2013) and as compared to countries from the former Eastern-European block (Byerly, 2011) (Table 1). The diagnosis of these two reports put together indicates that more than half of tertiary level graduates for mediarelated careers in Poland are women and women make up nearly half of the media industry workforce. However, there are important gendered patterns that emerge: women are very close to parity with men in terms of overall numbers in the newsrooms and news-gathering and production roles at the junior and senior professional levels, but are seriously under-represented in the technical roles and over-represented in the ranks of sales support, finance and administration. When looking specifically at decision-making positions, the general trend is that women's participation increases as the level of the position decreases and both reports point to the existence of a glass ceiling in Poland in the media industry. The term glass ceiling refers to an invisible but nonetheless real barrier that women are likely to encounter at the workplace. If at a certain occupational level women constitute at least $40 \%$ of the labor force, but above that level their participation in the company's structure drops significantly, it can indicate that a glass ceiling exists in that place (Byerly, 2011, p. 28). The EIGE report points to the existence of the glass ceiling in Poland already at the level of middle management, whereas the IWMF report finds the glass ceiling at the senior-management level in the media industry (Table $1)$.

Karen Ross, who was responsible for the EIGE research, explains that the study did not find a direct link between the existence of gender equality policies in organizations and high number of women in decision-making positions. Rather, findings pointed to cultural context at different organizational levels as most significant for women's career prospects. Ross further confirmed what other researcher find, namely that women are mostly overlooked for promotion for reasons other than their competence (Ross, 2014, p. 47). Nevertheless, both the EIGE and the IWMF reports stress that without substantial structural changes, the process of achieving gender equality in the media sector is going to be slow. The IWMF report also points to problems of corruption and lack of transparency as still common in media institutions in the Eastern-European region.

Dobek-Ostrowska points out that a common problem of Central-Eastern European countries, amongst others, is the general low quality of democracy, seen in the unhealthy relations between political actors and the public institutions (2011, pp.45-47). The process of consolidation of democracy in this region is hampered by political parallelism or what Herbut calls "the colonization of public administration" by the ruling parties (Herbut, 2002, p.110). To ensure their strong and lasting position, ruling parties take control of public organizations, local government, non-public institutions and most importantly the public media, by placing party people in key positions in those institutions. In Poland, all public media institutions remain "colonized" by ruling parties since 1993, when reforms of electronic media after the fall of communism were introduced and the Radio and Television Act took effect.

In the opinion of the media expert Karol Jakubowicz, the corruption of the media system that followed after the reforms, was not due to a flawed 
law. The legislator made sure that politicians were deprived of the right to directly appoint public media authorities. However, due to immaturity of the democratic system and a poorly developed civil society, the "political colonization" of the National Broadcasting Council, which nominates the supervisory and management boards of all public media institutions, became officially legal after 2005. An amendment has been introduced to the initial Radio and Television Act that basically legalized a spoils system in the media, bringing Poland closer to particracy rather than democracy (Jakubowicz, 2007, p. 228). Almost three decades after the fall of communism, the country is still not able to develop a transparent system to promote people to public offices, nor sufficiently control the actions of politi- cians (Dobek Ostrowska, 2011), making the struggle for gender equality advancement in the Polish media particularly difficult.

In what follows, I first examine the oppressive organizational structure of TVP, as experienced by its employees (findings section); and next, I argue that the resulting hegemonic organizational culture, imposes unequal work demands on women in the organization and leads, even the female senior managers in TVP, to engage in defending the status quo by resisting women who violate the existing gender order by reaching for the "forbidden" top positions in the organization (Rudman et al., 2012) (discussion section).

\section{Method}

\subsection{Theoretical perspective}

Research presented in this paper is part of a $\mathrm{PhD}$ project "Gender in a media institution on the example of TVP S.A.” where I explored the gendered normative frameworks, practices and principles TVP, as an organization, sets and follows, in regards to its recruitment policy, promotions, education, socialization, terms and conditions of employment and the consequences of these processes for the institutionalization of gender inequality in TVP. The relationship between gender equality and organizational structure is seen as actively sustained by power agents with interests in sustaining these inequalities. It is an active process of organizing social life of the organization, meaning that it can be organized to either depart from or reproduce the initial situation of inequality. In other words, social reproduction of gender inequality in an organizational setting is merely a possibility, not a necessary, unavoidable empirical outcome. However, for the processes that reproduce gender inequality to persist, they need to become stabilized (institutionalized) and that can only be done to the extent that groups who constitute a particular network (organization) have interest for these processes to remain unchanged. In other words, inequalities have to be maintained (Connell, 1987, p. 139-141). Practices, both formal and informal, that reproduce gender inequality in organizations include recruitment processes and who has access to promotion, organization of the work process and who gets to perform interesting tasks and benefit from perks (such as a company car), personal policies such as who gets to enjoy employment security, salary and other cash prizes (Kvande, 2003, p.33).

Studying every-day practices and relations between people working in organizations allows one to read the underlying structural and ideological constraints that set limits on possibilities people have within these organizations. In other words, what types of tasks women and men are allowed to perform, what they believe, how they are allowed to behave and how they are ranked and valued within any given organization, shades light on the socially and historically constructed organizational structures and cultures (Kvande, 2003, p. 35).

\subsection{Methodology}

Ethnography is useful for studying how unequal representations in specific occupations come about and how cultural values are transmitted to create institutional inequity (Fetterman, 2010, p. 3). As the objective of the study is to answer the fundamental question: why the progress in implementing the principle of gender equality in the media sector 
in Poland is slow, ethnography was my choice of research method. In turn, the choice to study organizational culture of Polish Television (TVP) was not accidental. As was already mentioned, TVP is the largest media organization in Poland, it is a public institution and as such it is obliged both by national and international law to implement and comply with gender equality policies, and thirdly this is the institution I, as a researcher, had access to.

This ethnographic study examined organizational culture of TVP, as experienced by its employees, during a period of six months. Participatory observations and in-depth interviews with 23 male and 27 female employees were carried out during two distinct, yet overlapping periods. From December 2013 till February 2014 I worked alongside TVP employees on a life-style morning show, in the course of approximately three editions per week. From January till May 2014, I worked on a publicaffairs program, in the course of five editions per month. In both periods, in the position of a junior editor, I participated in all newsroom operations necessary for preparing the program. Field notes included evidences of practices, routines and policies. In-depth-interviews to gather information on TVP employees' experiences, perspectives and beliefs, were conducted with all employees alongside whom I've worked on the program, as well as with managers and administrative staff who did not work directly in the same newsroom as I did. As a former employee of TVP, I had contacts with colleagues and used these networks to help identify potential interviewees. Further contacts were accomplished by snowball sampling and newly established contacts in newsrooms where field study was contacted. The sample was controlled by gender, role in the newsroom, position in the organization. Most of the interviews were conducted outside of the workplace, in cafes, pubs or in private homes. Some, however, were carried out on TVP's premises, during breaks, in empty offices. This article refers primarily to the experiences and opinions of employees who occupied senior and middle managerial positions in TVP. People from the highest levels of the organization refused to participate in the study.

Interviews were transcribed and treated as text (van Zoonen, 1994). Next, both the field notes and the interview text were coded, following key concepts and points that emerged from the data and reveled the nature of the organizational culture of TVP. For example stories and myths surrounding recruitment, hiring and promotional practices were analyzed. Data was also examined for different types of interactions and communication patterns between managers and employees, managers amongst themselves and employees amongst themselves that revealed the general workplace atmosphere and working culture of the organization.

\section{Results}

The in-depth interviews and extended period of ethnographic study offered deep insight into gendered relations, cultural norms and management practices as experiences by TVP employees and demonstrated how an oppressive hegemonic structure, first created during communism and today maintained through political parallelism (DobekOstrowska, 2011), became part of TVP's organizational culture.

What struck me several times during the interviews was the fact that a great number of employees didn't acknowledge the idea that a glass ceiling exists in TVP. The existence of the ceiling is clearly visible in the statistics, yet for many TVP employees this explanation had no justification. Employees pointed to the fact that TVP informally functions as two parallel institutions - 'political TVP' and 'working TVP' - and when they were asked about women in key decision making positions they referred to the newsroom level, as level where the workers formal influence ends.

"Journalism and management are two separate groups of people, which are not connected to each other. Management is like politics, how many politicians do we have and how many of those are women? If a woman had such 'political shoulders' as 
the current TVP president she could have been in his position.” (Bruno, manager in the newsroom, 12 years in TVP)

"The fact that there are so many men in positions of powers is due to the fossilization of the institution and the fact that these positions are combined with politics. And politics are dominated by men, and the 'old boys' network', what can I say, men promote each other, they distribute these positions amongst themselves, ..., if you occupy management positions in TVP you have to fight with politics." (Stella, senior professional in the newsroom, 10 years in TVP).

The newsroom level is also the level in media organizations in Poland where women are relatively well represented in key-decision positions (Table 1: $44 \%$ of managers in newsrooms are women) and where their presence is established. However, the organizational structure of TVP doesn't end in the newsroom and after clarification that the question refers to the highest executive positions and the president of TVP, I learned that "it has always been a company where contests are dependent on political colors, therefore I don't know how to explain this, whether women do not work in politics?" (Kalina, manager in the newsroom, 20 years in TVP). Employees not only accept such division, but also most of the interviewees were convinced that contests for top managerial positions, even if they were formalized, were always "semi transparent", that new mangers were "brought in briefcases" (meaning they were appointed outside of TVP) and that "political connections" and "networks" were more important than one's skills and experience. The career ladder for creative and administrative workers in TVP is thus much shorter than it seems, available to the middle and senior management levels. These are also levels in the company's structure where relatively large numbers of women occupy power positions (Table 1).

What the employees are referring to, when they mention 'political TVP' and 'working TVP' is known as political parallelism or political colonization of public media institutions and is characteristic of the current Polish media system. 26 years after the political transformation it can be said that just as during the communist period all conflicts in the country focused on who has access to and control over mass media (Curry, 1982, p. 104), so today all conflicts in the country concentrate around access to and control over public media. The current media system guarantees the ruling party's full control over the public media (Dobek-Ostrowska, 2011, p.45). The fall of communism in 1989 did not therefore eliminate the nomenklatura system from the Polish media. Instead, the nomenklatura of a single Communist Party was replaced by a multiparty one (ibidem: p.47). The tradition of nomenklatura initiated during communism meant that key positions in the public administration, including in the media, were appointed on the Communist Party's recommendation (Gwiazda, 2008 , p. 6). The fact that today in Poland one can accurately determine the political affiliation of the president of public television proves that nomenklatura is still practiced by the ruling elites (Jakubowicz, 2007, p. 226; also Dobek-Ostrowska, 2011, pp. 45-46). For TVP employee, many of whom were working in TVP during the communist era, this practice is so obvious that it becomes invisible, but nevertheless nepotism and corruption were the two most common explanations when employees were asked about recruitment and personnel policies in TVP. Other consequences of the permanent crisis of management caused by political parallelism include:

- Political changes that take place every few years in the country result in permanent restructuring and management turnover in TVP;

- Non-professionals and so-called 'political paratroopers' are nominated to key positions in public media institutions, making them unavailable to qualified employees;

- The new management mistrusts the employees (Jakubowicz, 2007, p. 252).

Another consequence of the "political colonization" of TVP is the tradition of 'cleaning' the institution from the so called 'inherited' people or 'people of the rival crew'. This tradition apparently started during Maciej Szczepański's presidency in TVP (1972-1980). Sczepański, close associate of the ruling Party's First Secretary Edward Gierek, took office in 1972 and quickly earned his nickname 
'bloody Maciej' as he began his presidency in TVP with extended layoffs. In the history of this institution it was the first purge of personnel on such scale (Wojtyński, 2011, p. 10). Szczepański, in an interview published recently, admitted that when he began his presidency Polish television was like the Augean stables. Szczepański therefore, like Heracles, rolled up his sleeves and began to 'clean'. Approximately 450 people lost their jobs because according to Szczepański "five thousand people were employed, yet there were no specialists" (Modrzejewska, 2015). Apparently it was not about imposing one's will through fear, but about ridding the institution of "wives, mistresses, lovers, fallen VIPs and so-called specialists who didn't have any qualifications to work in radio or TV" (Pikulski, 2002, p. 136).

Both the language and the tradition of 'cleaning' have since become an integral part of the organizational culture of TVP. Longtime television employees in their memoirs speak of "losers", "waste", "deportees" of which each time new authorities had to 'purify' television from. Zoja, a senior professional in the newsroom, who has been working in TVP for 40 years, stated that exemptions related to the political change are a standard procedure in TVP.

Political cleaning mostly affects workers occupying senior management positions, from the 3 - 4 levels of the organization (Table 1) and for this reason these positions are referred to by employees as 'the carousel'. One can ride the carousel only for a short period of time. If a middle level manager is promoted to a senior managerial position, outside of the newsroom, the rule is that his/her return to the newsroom most likely won't be possible. As Melania, a manager in the newsroom with 31 years of experience in TVP, explains:

\footnotetext{
"The carousel of positions in this company means that once you were a boss with the next political change you will have to seek work outside television. I know exactly of one person who after the political change, went back to what he was doing before the promotion. Most people have to leave after their managerial ride, which doesn't mean that at one point they won't come back for another ride on the carousel."
}

The explanation of this rule is very simple. Since all power positions in TVP are connected to politics, anyone who occupies such a position becomes associated with politics. Even if their promotion was achieved through hard work and years of experience, they become 'people of the rival crew' once new political elites take over the governance of public media.

Uncertainty of work on "the carousel" dissuades many people from accepting promotion to senior management positions. Apoloniusz, a manager in the newsroom with 17 years of work experience in TVP, turned down a promotion for this reason. As he explains: "I know these mechanisms here. You can only be a director for a short while and after that it is difficult to come back to the newsroom. So I said I prefer to do my thing”. However, I heard this argument from women much more often. As women's political networks are weaker they are much more cautious than men when it comes to accepting positions on "the carousel." Melania, continues:

"Women who work here are very aware of the seasonality of the power positions, therefore, they do not want to go there ... we have a very strong political arrangement here and men are more active than women in politics. There are many wise women here, but they prefer to do their jobs. Professionally they are doing what they should be doing and they don't get involved in political games."

Lucyna, with 25 years of work experience in TVP, also occupying a managerial position in the newsroom:

"I went through all possible positions here except the managerial ones. These I do not wish to my worst enemy,..., managerial positions are screwed, absolutely, precisely because of such issues as nepotism, limited possibilities and corruption which no one wants to admit they exist but once in position, for example as department manger they know they can't fire certain people who should normally be expelled due to lack of qualifications."

Occupying managerial positions in the newsroom (level 5) is safer in regards to employment security. This does not mean, however, that the creative staff 
in the newsroom is not affected with each political re-organization and that people maintain their positions and working conditions. Workers in newsrooms, including full-time employees, work according to newsroom schedule. Each month their income depends on whether or not they have been included in the newsroom schedule. For example, if a senior editor's name disappears from the schedule, this does not mean that $\mathrm{s} /$ he is fired from TVP, only that $\mathrm{s} / \mathrm{he}$ just lost the opportunity to earn in that particular newsroom. As the remuneration system in public media is based on a minimum basis supplied by royalties for all activities one performs in the newsroom, it is very easy for the new managers to control and discipline newsroom staff by simply removing them from the schedule. This system of royalties has been developed and implemented during communism, where due to staff shortages the censorship authorities struggled to maintain a firm grip on the publications and programs prepared by television and radio employees. The censorship system that was developed on one hand controlled key positions in all state media institutions by filling them according to the Party's nomenklatura. On the other hand, financial pressures on journalists and columnists made it easier for the Party to persuade workers to write according to the Party's line. Self-censorship forced by royalties ensured that even if journalists possessed information that was inconvenient for the Communist Party, they would not waste time preparing publications, which they knew in advance, would not pass the censor's desk (Curry, 1982, pp. 106- 107). Middle level management therefore, at least, has the possibility of migrating within the company, i.e. searching for assignments in other newsrooms or departments of TVP, if the new political current turns out unfavorable for them. Michał, a senior manager in the newsroom with 13 years of work experience in TVP, explains:

"Often if someone was promoted to managerial post in the newsroom because they are good, when the top elite changes they are considered 'from the rival crew' and removed from the position. The ban will last a few years, and after another political change, those who were worse off are now better, and those who were better off are now worse and so the circle goes. Those who work 'on screen' have even a bigger problem."

This type of work arrangement means no one can ever feel safe in their position. Melania explains:

"It's a constant rollercoaster. Either I'm at the top or at the bottom. Either somebody says I'm an idiot, or that I'm super clever. In such moments, when your position in going down without any legitimate reason, no one ever explains anything, I perceive TVP to be a hostile organization. For example, in the last years I worked in one newsroom, as a senior editor. Suddenly the new schedule arrives and I am not there. Despite the fact the new boss talked to me and assured he wanted to work with me, but when the schedule arrived it turned out I only had 5 shifts this month!”

As Michał mentioned, not only managerial positions are 'cleaned' after political reshuffles at the top, but also the cast of the most prestigious primetime programs. The schedule method is also applied here. Some young employees perceive this practice as natural. Witalis, senior professional in the newsroom with 6 years of work experience in TVP, says: "Sorry, club law applies here. The boss can choose whoever he wants to work with." However, most employees see the club law, in the words of a longterm TVP employee Tadeusz Zakrzewski, as a hostile practice that basically comes down to management nominating people "to be gunned down." This method has been practiced since the inception of Dziennik Telewizyjny, the main news program broadcasted during communism from 1958 till 1989, the central propaganda tool of the Communist Party. "Each time a new team took over leadership in the Communist Party, the so-called disgraced faces were removed from the screen, as the new leaders at the expense of most recognized journalists, wanted to gain credibility in the eyes of the society" (Zakrzewski, 2003, p. 8). To this day, commentators and presenters are at risk of losing their jobs after each political change. Neither experience, awards, recognitions nor the 'star' status are relevant if one is nominated to be "gunned down". This practice makes TVP a hostile and unpredictable institution. Gniewko, a manager in the newsroom with 14 years of work experience in TVP, explains: 
"On the one hand I had a briefcase full of certificates, letters of praise and rewards, but the moment I started to question decisions of the new management crew my "portfolio" didn't matter anymore. How could that be? That in one second you are deemed not suitable for the job? There is no such thing as a career path in TVP. You cannot predict anything here."

Witold, a senior professional in the newsroom with 5 years of work experience in TVP:

"I experienced huge personal upheavals here. I was on the top, after returning from a mission I received the TVP President's Award for dedicated service, and two months later I was fired. The director changed, and the new one said my position in the newsroom was too strong and I lost my contract. He said I could stay but only as a self-employee.”

The "rollercoaster" not only does not let people feel safe in this organization but above all, in the eyes of many employees is a degrading and humiliating practice. Most interviewees, both male and female, reported they feel that nobody cares and respects their work. Here are some bitter reflections on the experience of working in TVP:

“This company doesn't respect the people who work here and devote their life to this institution. I am an example of this. I've been working here for over 20 years without a real job contract! I've done everything here, from live reporting to cinematography, to video editing. Yet, nobody ever told me I am needed here. After all, isn't a job contract such a confirmation?" (Gracjan, a male manager in the newsroom, 21 years in TVP)

"At the moment I am depressed, I feel completely humiliated. From good position, from being the face of the most important news program, you know you are making some steps, you think you are growing professionally,..., at some point one of the private stations wanted to hire me so TVP offered me a 'superstar' contract so I would stay here. But this was a one-year contract and in the meantime the management changed, they brought new girls with them, who from being weather presenters suddenly became news anchors, and I was relegated to a substitute position." (Klara, a senior professional in the newsroom, 8 years in TVP)
Trust, which the whole 'cleaning' practice allegedly is about, affects the management - staff relations. With each change, the creative staff is not only afraid of losing their position in the company, but they also fear the type of management style and professional competences the new bosses will bring to the company. "We are always excited if the managerial position was taken by someone who has at least a vague idea about television work" (Lucyna, a manager in the newsroom, 25 years in TVP). Stories about how bakers or electricians are taking executive positions in TVP are part of the organizational culture of this institution. When asked whether the sex of the new boss was important, most people answered that it was the intelligence and professionalism that was important to them, not the sex of the new boss. Manuela, with 35 years of work experience in TVP, who occupies a managerial position in the newsroom, explains why each management change makes her worried about her job:

"Each time I'm afraid of how my cooperation with these new people will look. Once a new director turned out to be former director of a sugar factory. He had no idea about journalism. Currently the boss is our former colleague from the newsroom and we love him! He is trying to do something. I don't know how much strength and time he will be given, but I pray every day that he stays here."

The employees of TVP suffer the consequences of bad decisions made by individuals without appropriate experience or skills. New management often arrives with ideas to restructure the company, however, the only good that comes out of restructuring, according to the employees, is "disorganization", "chaos", and "overwhelming bureaucracy."

"The omnipresent administration. Tons of papers. I have so many papers, tons of papers to fill, everything needs to be printed. It's beyond me. To give out a cassette I have to fill out a paper, then another paper for the archives, this is a terrible foolishness. When I hear there will be another restructuring, I know that more papers to fill out are coming". (Manuela) 


\section{Discussion}

In the findings section I have demonstrated what consequences, the socially and historically constructed oppressive organizational structure of TVP, has for the employees. In the following section I will argue that the resulting organizational culture, is not only actively maintained by people who have political power in the country but, in turn, is stabilized by ideological sex-stereotyping, that allows for the practice of gender discrimination to remain unchanged. Because organizational structures legitimize certain cultural and normative beliefs and discourses about power and femininity and masculinity, in it not surprising that in an environment where the top power positions in the organization are politically corrupted, amongst those who engage in defending the gender hierarchy, are also female managers. Inasmuch as TVP employees understand the organizational order of public television, they still need to be able to legitimize the existing social structures. Researchers have shown that our needs to legitimize existing social structures are pervasive and often nonconscious, and that defending the gender hierarchy is the key motive for why people engage in discriminatory practices and reject women who disrupt the status quo (Rudman et al., 2012). In turn, the hegemonic gender hierarchy, places unequal expectations on women in the organization, as if expecting them to 'prove' their suitability for the decision-making posts.

\section{1. "I shouldn't have tried to reach for $i t^{\prime \prime}$}

One obvious consequence of the politicization of the recruitment and promotion processes in TVP, namely the granting of key decision-making positions through political networks, is that people who have no access to such networks are automatically eliminated from the recruitment processes (Collinson et al., 1990). Political parallelism however, has additional consequences for female TVP employees. As the corrupted system becomes part of the organizational culture and the hierarchical gender order is taken for granted by TVP employees (us 'workers' versus them 'politicians' mentality), rejecting women who disrupt the status quo, by reaching for the top positions in the organization (for the "for- bidden fruit"), becomes justified, even amongst senior female managers in the organization.

Power positions in TVP are associated with masculinity. A good manager is someone who behaves in a masculine way. This culture of management is reinforced by the "old boys club" and is not questioned by TVP employees for a very simple reason. Anyone who protests against these practices is at risk of losing their job. When Celestyna, a senior manager with 17 years of work experience in TVP was asked "Which experience of working in TVP do you most remember"? she answered:

"Fake competition which the TVP President organized. I applied for this position unaware that everything was already decided,..., for half a year a media smear campaign happened against me. I reached for the forbidden fruit. That (position) was reserved for a very small group of buddies. I shouldn't have tried to reach for it."

These statements "I reached for the forbidden fruit" and "I shouldn't have tried to reach for it" are very symbolic and show how the corrupted by politicians structure of the company becomes accepted as "this is how things are." Given the manner in which discriminatory practices of recruitment, promotion and organization of work have been institutionalized in TVP, one can suggest an alternative to the official organizational chart of the organization (Table 1). Positions from the first and second level of the organization and partly also from the third level of management are completely out of reach of TVP employees, as they are awarded according to the nomenklatura. Positions from the third and fourth levels of the organization are very unstable and referred to as "the carousel". The "rollercoaster" characterizes the fifth management level and partially also the senior professional positions in TVP. Managers who participated in this research came from the "the carousel" and "the rollercoaster" level of TVP, as the first and second level of the organization, turned out to be completely out of my reach, as the researcher. 
Table 1: Women's representation at different levels of media organizations in Poland.

\begin{tabular}{|c|c|c|c|}
\hline \multicolumn{2}{|c|}{$\begin{array}{l}\% \text { of women occupying positions within different levels of } \\
\text { media organizations in Poland }\end{array}$} & \multirow{2}{*}{$\begin{array}{c}\text { EIGE report } \\
\begin{array}{c}\text { Poland } \\
\text { (EU) }\end{array} \\
18 \% \\
(25 \%)\end{array}$} & \multirow{2}{*}{$\begin{array}{c}\text { IWMF report } \\
\begin{array}{c}\text { Poland } \\
\text { (East Europe) }\end{array} \\
29,5 \% \\
(32,9 \%)\end{array}$} \\
\hline \multirow{3}{*}{$\begin{array}{l}\text { Top } \\
\text { management \& } \\
\text { governance/ or } \\
\text { Nomeklatura }\end{array}$} & Level 1: Board members & & \\
\hline & $\begin{array}{l}\text { Level 1: Chief Executive Officer, Chairperson, } \\
\text { President, Director General }\end{array}$ & $\begin{array}{c}\mathbf{0} \% \\
(16 \%)\end{array}$ & \multirow[b]{2}{*}{$\begin{array}{c}25 \% \\
(43,4 \%)\end{array}$} \\
\hline & $\begin{array}{l}\text { Level 2: Chief Operating Officer, Executive } \\
\text { Director, Editor-in-Chief. The person holding this } \\
\text { position is likely to chair the most-senior } \\
\text { operational decision-making committee/s. }\end{array}$ & $\begin{array}{c}\mathbf{0} \% \\
(21 \%)\end{array}$ & \\
\hline \multirow{2}{*}{$\begin{array}{l}\text { Senior } \\
\text { management/ or } \\
\text { "the carousel" }\end{array}$} & $\begin{array}{l}\text { Level 3: Heads of Departments, Acting Directors, } \\
\text { and Management team members. For example } \\
\text { Director of News, Director of Human Resources, } \\
\text { Director of Administration }\end{array}$ & $\begin{array}{c}29 \% \\
(32 \%)\end{array}$ & \multirow{2}{*}{$\begin{array}{c}41,9 \% \\
(40,9 \%)\end{array}$} \\
\hline & $\begin{array}{l}\text { Level 4: Heads of Divisions which are responsible } \\
\text { for sub-areas: Head of News, Head of Sport, Head } \\
\text { of Culture, Head of HR and Head of a Management } \\
\text { Unit }\end{array}$ & $\begin{array}{c}30 \% \\
(36 \%)\end{array}$ & \\
\hline \multirow{2}{*}{$\begin{array}{l}\text { Middle } \\
\text { management/ or } \\
\text { "the } \\
\text { rollercoaster" }\end{array}$} & $\begin{array}{l}\text { Level 5: Management in newsrooms, for example: } \\
\text { Senior Editors, Chief of Correspondents, Creative } \\
\text { Director and more senior staff in Human Resources } \\
\text { and Finance }\end{array}$ & $\begin{array}{c}44 \% \\
(32 \%)\end{array}$ & $\begin{array}{c}43,8 \% \\
(49,8 \%)\end{array}$ \\
\hline & $\begin{array}{l}\text { Senior-Level Professionals: senior writers, } \\
\text { editors, anchors, producers, researchers, reporters, } \\
\text { correspondents }\end{array}$ & & $\begin{array}{l}45,6 \% \\
(56,4 \%)\end{array}$ \\
\hline \multirow{3}{*}{$\begin{array}{l}\text { Creative } \\
\text { positions }\end{array}$} & $\begin{array}{l}\text { Junior-Level Professionals: junior/assistant } \\
\text { writers, producers, anchors, directors, reporters, } \\
\text { sub-editors, correspondents, }\end{array}$ & & $\begin{array}{l}58,8 \% \\
(59,9 \%)\end{array}$ \\
\hline & $\begin{array}{l}\text { Production and Design: scene designers and } \\
\text { construction workers, graphics designers, wardrobe } \\
\text { designers, make-up artists, film/video editors }\end{array}$ & & $\begin{array}{c}28,4 \% \\
(33,9 \%)\end{array}$ \\
\hline & $\begin{array}{l}\text { Technical Professionals: camera, sound and } \\
\text { lighting technicians. }\end{array}$ & & $\begin{array}{c}3,7 \% \\
(20,5 \%) \\
\end{array}$ \\
\hline $\begin{array}{l}\text { Sales, Finance \& } \\
\text { Administration }\end{array}$ & $\begin{array}{l}\text { Marketing, sales and public relations specialists, } \\
\text { accountants, human resource staff, clerks, } \\
\text { secretaries. }\end{array}$ & & $\begin{array}{c}65,8 \% \\
(69,4 \%)\end{array}$ \\
\hline
\end{tabular}

Source: Own elaboration

Researchers who study gender discrimination within organizations indicate that transparency in recruitment, promotions and pay, are important institutional procedures that can eliminate the phenomenon of the glass ceiling from organizations (Rudman \& Phelan, 2008; EIGE, 2013). In institutions where these practices are far from being transparent, one can expect gender stereotypes to be more salient as both women and men are far more likely to resort to stereotypes and prejudices when no clear criteria are available for judgment and evaluation. These ideological constraints further alienate women who happen to find themselves amongst power elites. Not surprisingly, combining power with masculinity and politics is regarded by
TVP employees as something natural. Such essentialist gender ideology was strongest when people were referring to senior managerial positions in the organization and confirms what researchers have found, namely that women who try to disrupt gender hierarchy experience the strongest prejudice (Rudman et al., 2012). As was already mentioned, when people were asked whether the sex of the new boss was important to them, most answered that intelligence and competences were far more important. However, amongst those who preferred a male boss, stereotypical opinions prevailed about women in power positions and they became more explicit as the level of responsibility rose. Celestyna, the already mentioned female manager, 
when asked about her preferences without hesitation replied: "If I had to choose between a competent guy with a good personality and a hysterical lady then why would I choose her? I prefer to work with men because they are more decisive", taking it for granted that a woman manager would have to be a hysterical person. Upon asking whether her opinion would change, if the potential woman had a good personality, she replied: "If she was a decisive woman, no problem. For me it is not a matter of gender, but certain personality traits that make it easy to work with such a person. Merits should decide, not sex", smoothly going back from personality traits to competence. This mechanism is well known among psychologists who study the effects of stereotyping during interviews. Bowles, Babcock \& Lai showed that women in situations of recruitment or negotiations are evaluated for different characteristics than men. Once women's professional qualifications have been confirmed, they are assessed for social skills. This effect does not occur in the case of male candidates (2007; see also: Rudman \& Phelan, 2008). Approx. $30 \%$ of all people who were interviewed in this study, both men and women, for similar reasons felt that their supervisor should be a man. Women in decision-making positions, those from "the carousel" level and higher, turned out to be worse bosses for reasons that coincided with cultural stereotypes about gender. Professional qualifications of potential women managers were not at all mentioned, instead I heard that women in power positions are vicious, false, less concrete than men, more moody, emotional and conflict prone and are more preoccupied with gossip than men. A typical opinion of a female journalist who expressed her belief that managers need to possess male characteristics: "Never in my life would I accept a managerial position in this company,..., you have to be a butch type of a woman, able to put your foot when needed or throw a fit" (Klara, a senior professional in the newsroom, 8 years in TVP). Idalia, also a female manager in the newsroom with 20 years of work experience in the media: "In the newsroom I have always had women leaders, but all the CEOs were actually men. If a woman was offered a promotion, it was on the principle that she was an iron woman, nasty, a slut or a drunkard, or no one wanted to have sex with her. There was always a flaw". Ada, a senior female manager with 16 years of work experience in TVP: "women in power positions behave like men, I don't understand why. Even in their body language,..., Agnes was a very nice lady and once she became a boss she became worse than the guys, she even started to dress like a man.”

Female managers who participated in the study, from "the carousel" level of management in TVP, applied even stricter criteria when evaluating female bosses from the nomenklatura level. From Brunona, a senior manager with 17 years of work experience in TVP, I heard: "The top positions are reserved for nasty women." The organizational structure of TVP fosters a culture that aggressively devalues everything that is regarded as feminine, forcing women to adapt to such oppressive ideologies and even engage in defending the gender status quo, by either rejecting women who reach for the "forbidden fruit" as nasty and unwomanly (as can be seen in the statement of Brunona), or by coming to terms with the fact that power positions are not for women (as can be seen in the statement of Celestyna):

"A woman in TVP can reach the level of a vicedirector at the most, but only if her parents agree to raise her children. Women who achieve highest levels are childless, have no empathy and immediately take on masculine roles in the organization" (Brunona);

"There are areas in the structure of television, where only men should be. They have the privilege to be able to switch off their personal life. Because even if a single woman gets promoted she will still miss people after spending hours here every day. And either she will become like a man and adopt behaviors completely unnatural for us, or she will exaggerate. This may not seem cool, but there are areas in life where men should be allowed to dominate. Because the can, because this is how they have organized this world, to be able to withdraw and forget about God's world" (Celestyna).

The seemingly natural barriers women face when reaching for top decision-making positions, that Celestyna mentions, namely long working hours, requirements of full availability and flexibility, the 
need to separate work from personal life, these are all features of work that privilege masculinity (O'Brien, 2015). However, it is worth noting that these expectations seem only problematic for women who aspire to decision-making positions and therefore are ideological in nature. There are some facts that confirm this. Firstly, the nature of journalistic or so called 'creative' work is exactly the same. In fact, television employees are always required to be flexible and work in non-standardized hours. "You never know the day or the hour" is a popular expression journalists use to describe their work. Yet, there is gender parity in the newsrooms, with women occupying almost $50 \%$ of all decision making positions. This fact negates the argument that women are unable to 'sacrifice' family life and reconcile work and personal life. Opinions expressed about women in decision positions in newsrooms are much more diverse and gender stereotyping practically does not appear. Employees rather draw attention to the intelligence and competence of managers rather than their sex. Furthermore, the argument that men are not 'burdened' with personal lives is refuted by some men, including men in leadership positions who have in the past refused promotion opportunities or resigned from projects if they felt these would interfere with their family life. The statement by Gracjan, occupying a managerial position in the newsroom, with 21 years of work experience in TVP, shows that also men are not always willing to work at any price:

\footnotetext{
"When my daughter was born, work was very intensive. I was gone for 4 days and only came home to repack and would leave again. I functioned this way until the day when my daughter, who was one year and two month old at that time, saw me in television and started kissing the screen and screaming daddy, daddy. She hasn't seen me for two months at that point. And it was a shock to me. I decided to put an end to that and changed my priorities, changed how I was working. Some projects I had to give up, but this was like a bucket of cold water on the head."
}

Nikodem, a senior professional in the newsroom, with 10 years of work experience in TVP, who tries to maintain the balance between family life and work, when asked if he felt he had to sacrifice something to be in the position he is in today, replied:

"No, sometimes I have opposite reflections and wonder that perhaps I should be sacrificing my private life a little more for the sake of my career or something like that? But then there are moments that put me back in the right perspective. Like when I see people who for years left the TVP building at 22:00 only to discover one day that their ID card has been deactivated. They were fired and no one even said thank you."

\subsection{Hard-working "loonies"}

Women who aspire to senior managerial positions find themselves in a Catch-22 situation. In order to be perceived as qualified they must present themselves as decisive and assertive, yet when they do behave in such a way, they risk experiencing prejudice for behaving counter stereotypically (Rudman et al., 2012). One of the strategies women in such situations may adopt is become extra diligent. Still, this strategy may or may guarantee success.

"When I was a director, all my deputies were always women. The reason being that women are more hard-working than men. It is a separate question whether they need to be so hard- working, but I am simply stating a fact, that they are,..., Perhaps the reason why there are more men in power positions in the media is how stressful this profession is. Men focus on work differently from women. They pay attention to different things. Perhaps this makes it easier for those who decide about promotions to nominate men? In addition to very decisive women. There is a group of women who are very decisive, precise, perfectly able to delegate tasks, etc. But also these women must be careful not to come off as loonies. Because a guy will be concrete and firm and a woman can be a loony". (Franciszek, senior manager, 25 years in TVP)

Franciszek's opinion about women in decision making positions perfectly captures the complexity of the problem, as well as confirms what has already been said. Namely, that the seemingly natural barriers women face when reaching for decision-making positions, as allegedly too difficult to reconcile with family life, is of ideological, misogynist, nature. 
Even if it is true that managerial jobs require long working hours and great devotion to the workplace, women are expected to put even greater number of hours and demonstrate even a greater commitment than men. They also have to come to terms with these double standards that relate to their work. Like in the case of senior female manger Brunona, who in a conversation with the president of TVP, drew attention to the fact that she was expected to complete a very complex task in an unrealistically short time, she heard: "If the task was easy I wouldn't have employed you." It is no wonder that the same manager believes that women are only offered a place on "the carousel" when the position is very demanding and no men is interested in it: "These positions on the carousel generally are taken. If there is a vacancy and they can't find a man who would like that job they will promote a women, let her toil!" (Brunona)

Honorata, a senior professional in the newsroom, with 11 years of work experience in TVP takes pride in her diligence: "In my last job I had a boss and he appreciated my diligence in this way that instead of hiring 6 people to do a job he could hire just 3 . He said he chose me because he knew how I work!" The fact that she was expected to literally do the work of three people, gave her a reason for satisfaction. The question one would like to ask in this situation is whether her effort was adequately financially rewarded? After all in a capitalist society people work for money, not for appreciation. Elwira, a senior manager with 18 years of work experience in TVP, experienced such expectations to be the case. When she was promoted from the position of a senior specialist to a managerial position, she asked for a raise. The increase in salary she asked for was supposed to match her salary to other managers. A raise she was able to estimate thanks to her financial position in the company. However, her request was declined and called unrealistic: "Everything has been blocked by people from the upper levels in the company, probably because the increase in salary was so big. For them it would be perfect if I agreed to the promotion without changing the salary." Elwira finally negotiated some raise, but she remembers this period as a very stressful and humiliating time.
Newsroom employees, whose salaries depend on royalties, were the only ones who thought that gender pay gap didn't exist in TVP. On the other hand, all female senior managers knew that their salaries were smaller than their peers. For Ada the answer to the question whether women in the same positions as men earned as much, was obvious: "No! I'm sure not, I'm sitting in a room with a colleague who in the same position as me and he earns 3 thousand more. It's depressing. I would understand if it was 300zk, but 3 thousand?” A similar number was mentioned by Brunona: "When I was promoted I inherited the desk after the previous director and I found his pay slip. He was making 3 thousand more than me."

Some employees believe that the reason why there is such a great number of women in decision making positions in newsrooms is due to the fact that work demands are growing, whereas conditions and pay are deteriorating. Researchers call this the "velvet ghetto" effect (EIGE, 2013, p. 33). Manuela, manager in the newsroom, explains:

"The majority of production managers are women. Very few men would withstand this stress. We had some but when they saw how much paper work is involved in this work they fled to another position. Now we have only two male production managers. Men prefer to do simpler things that are better paid and we are stuck with this heavy work load. This is not cool".

Kalina, also a manager in the newsroom, with 20 years of work experience in TVP, accepts this patriarchal order as natural:

\footnotetext{
"Women are more hard working and this is the reason why they are the main workforce here, while men are the bosses managing this group of women,..., This is connected to the fact that men simply expect to earn more money."
}

The fact that there are no official work assessment procedures in TVP makes the hard-working strategy a very risky one. Franciszek, a senior manager, when asked about work assessment in TVP replied: 
"Appreciation of one or another director. You can work your ass off here and nothing may come out of this. In contrast, it is often more important who you know, who you drink with and with whom you meet after work. But thanks to such [hard-working] people, this company stays afloat, these are passionate professionals.”

\section{Conclusion}

The consistent themes that arose among employees and middle level managers regarding TVP organizational culture were the lack of transparency in assigning decision-making positions, an atmosphere of fear and enemy-building managerial style, authoritarian and disrespectful communication between management and employees. Recognizing that the transfer of political power from communist to more democratic political leadership in 1989, did not contribute to dramatic changes in the public media structure and that political parallelism in public media in Poland has consequences for media independence and for employees well-being is an important step in understanding how gender inequality persists in the public media in Poland. This ethnographic study revealed that the socially and histori- cally constructed oppressive organizational structure of TVP, actively maintained by people who have political power in the country, is in turn stabilized by ideological sex-stereotyping against women in top positions, that even senior female managers engage in. This finding confirms what the EIGE report found, namely that women's presence in the workforce and women's presence in top-decision making are two separate issues (EIGE, 2013). Tackling issues of gender inequality in the public media in Poland has to start with recognizing that the problem of structural inequality in public media stems directly from politicians themselves, who far too often in recommendations of organizations such as the Council of Europe or the European Union are seen as the solution rather than the problem.

\section{References}

- Ammu, J. (2005). Making News: Women in Journalism. New Delhi: Konark.

- Byerly, C.M. (2011). The Global Report on the Status of Women in the News Media. Washington, DC: International Women's Media Foundation.

- Bowles, H. R., Babcock, L., Lai, L. (2007). Social incentives for gender differences in the propensity to initiate negotiations: Sometimes it does hurt to ask. Organizational Behavior and $\mathrm{Hu}$ man Decision Processes, 103, 84-103.

- Carter, C., Branston, G., Allan, S. (Eds.) (1998). News, Gender and Power. London, UK: Routledge.

- Connell, R.W. (1987). Gender \& Power. Society, the Person and Sexual Politics. Cambridge: Polity Press.

- Collinson, D., Knights, D., Collinson, M. (1990). Managing to Discriminate. London, UK: Routledge.

- Curry, J. F. (1982). Media Control in Eastern Europe: Holding the Tide on Opposition. In J.L.
Curry \& J.R. Dassin (Eds.), Press Control Around the World (pp. 104-127). NY, USA: Praeger Publishers.

- de Bruin M., Ross, K. (Eds.) (2004). Gender and Newsroom Cultures. Identities at work. Cresskill, NJ, USA: Hampton Press.

- Dobek-Ostrowska, B. (2011). Italianization (or Mediterraneanization) of the Polish Media System? Reality and Perspective. In D.C. Hallin, P. Mancini (Eds.) Comparing Media Systems Beyond the Western World (pp.26-50). Cambridge, UK: Cambridge University Press. doi:10.1017/CBO9781139005098.004.

- European Institute for Gender Equality (2013). Review of the implementation of the Beijing Platform for Action in the EU Member States: Women and the Media -Advancing gender equality in decision-making in media organisations. Luxemburg: Publications Office of the European Union.

- Fetterman, D. M. (2010). Ethnography. Stepby-step. Third edition. Applied social research 
methods series, V. 17. Thousand Oaks, California, USA: SAGE Publications.

- Gallagher, M. (1995). An Unfinished Story: Gender Patterns in Media Employment. Paris, France: UNESCO Publishing No 110. Available at: http: / / unesdoc.unesco.org/ images/0010/001016/101613eb.pdf

- Goban-Klas, T. (1996). Politics versus the media in Poland: A game without rules. Journal of Communist Studies and Transition Politics. Vol. 12, Iss. 4, 24-41.

doi:10.1080/13523279608415321

- Gwiazda, A. (2008). Party Patronage in Poland: The Democratic Left Alliance and Law and Justice. East European Politics and Societies, 22 (Fall), 802-27.

- Harrison, J. Sanders, K., Holtz-Bacha, C., Rodriguez Diaz, R., Gorpe, S., Ghanem, S., Ugochukwu, C. (2008). Women and the News: Europe, Egypt and the Middle East, and Africa. In P. Poindexter, S. Meraz \& A. Schmitz Weiss (Eds.), Women, Men and the News: Divided and Disconnected in the News Media Landscape (pp. 175211). New York and London: Routledge.

- Herbut, R. (2002). Teoria i praktyka funkcjonowania partii politycznych. Wrocław, Poland: University of Wroclaw Press.

- Jakubowicz, K. (2007). Media publiczne. Początek końca czy nowy początek. Warsaw, Poland: Wydawnictwo Akademickie i Profesjonalne.

- Kvande, E. (2003). Doing gender in organizations - theoretical possibilities and limitations. In E. Gunnarsson, S. Andersoon, A. Vanja Rosell, A. Lehto, \& M. Salminen-Karlsson (Eds.), Where have all the structures gone? Doing gender in organizations, examples from Finland, Norway and Sweden (pp. 15-39). Stockholm, Sweden: Centre for Women's Studies Stockholm University.

- Made, P., Lowe, C. (Eds). (2010). Glass Ceilings: Women and Men in Southern Africa Media. Johannesburg, South Africa: Gender Links.

- Mishra, S., Chen, X., Ning, Y., Chen, K., Kim, K.H. (2008). Women and the News: India and Asia. In P. Poindexter, S. Meraz \& A. Schmitz Weiss (Eds.), Women, Men and the News: Divided and Disconnected in the News Media Landscape (pp. 212-238). New York and London: Routledge.

- Modrzejewska, B. (2015). Prezesi. Oni rządzili TVP. Warsaw, Poland: The Facto Limited.

- North, L. (2009). The Gendered Newsroom: How Journalists Experience the Changing World of Media. Hampton, New Jersey: Hampton Press.

- O’Brien, A. (2015). Producing Television and Reproducing Gender. Television \& New Media. Vol. 16(3) 259-274 DOI: $10.1177 / 1527476414557952$

- Pikulski, T. (2002). Prywatna historia telewizji publicznej. Warsaw, Poland: Muza S.A.

- Ross, K., Byerly, C.M. (Eds.) (2004). Women and Media. International Perspectives. Oxford, UK: Blackwell Publishing.

- Ross, K. (2014). Women in decision-making structures in media. In A.Vega Montiel (Ed.), Media and Gender: A scholarly Agenda for the Global Alliance on Media and Gender (pp. 44-48). Paris, France: UNESCO Publishing.

- Rudman, L.A., Phelan, J.E. (2008). Backlask effects for disconfirming gender stereotypes in organizations. In A.P. Brief \& B.M. Staw (Eds.), Research in organizational behavior, Vol.4. (pp. 6179). New York, USA: Elsevier.

- Rudman, L.A, Moss-Racusin, C.A., Phelan. J.E., Sanne Nauts, S. (2012). Status incongruity and backlash effects: Defending the gender hierarchy motivates prejudice against female leaders. Journal of Experimental Social Psychology 48.165179.

- van Zoonen, L. (1994). Feminist Media Studies. London, UK: SAGE Publications.

- Wojtyński, M. (2011). Telewizja w Polsce do 1972 roku. Wydanie drugie zmienione. Warsaw, Poland: Warsaw University.

- Zakrzewski, T. (2003). Dziennik Telewizyjny. Grzechy i grzeszki. Warsaw, Poland: Książka i Wiedza. 


\section{Forma de Citación}

GOBER, Greta: Political parallelism and the case of women in management positions in public media in Poland. An ethnographic study. Revista Communication Papers, $\mathrm{N}^{\circ} 7$, páginas 80 a 95 . Departamento de Filología y Comunicación de la Universidad de Girona. Recuperado el _ de de 2 de: http://www.communicationpapers.es

Appendix: Pseudonyms and positions of people who participated in the study.

\begin{tabular}{|c|c|c|c|c|c|c|}
\hline $\begin{array}{l}\text { Level of the } \\
\text { organization }\end{array}$ & Pseudonym & Sex & Age & Position & $\begin{array}{c}\text { Work } \\
\text { experience in } \\
\text { TVP }\end{array}$ & $\begin{array}{l}\text { Work } \\
\text { experience in } \\
\text { the media }\end{array}$ \\
\hline \multirow{15}{*}{$\begin{array}{l}\text { "The } \\
\text { carousel" }\end{array}$} & Celestyna & Female & 44 & Senior manager & 17 & 17 \\
\hline & Brunona & Female & 39 & Senior manager & 17 & 17 \\
\hline & Ada & Female & 41 & Senior manager & 16 & 16 \\
\hline & Elwira & Female & 45 & Senior manager & 18 & 18 \\
\hline & Franciszek & Male & 54 & Senior manager & 25 & 25 \\
\hline & Idalia & Female & 40 & Manager in the newsroom & 1 & 20 \\
\hline & Melania & Female & 56 & Manager in the newsroom & 31 & 31 \\
\hline & Lucyna & Female & 46 & Manager in the newsroom & 25 & 25 \\
\hline & Kalina & Female & 44 & Manager in the newsroom & 20 & 20 \\
\hline & Manuela & Female & 55 & Manager in the newsroom & 35 & 35 \\
\hline & Gniewko & Male & 42 & Manager in the newsroom & 14 & 19 \\
\hline & Gracjan & Male & 43 & Manager in the newsroom & 21 & 21 \\
\hline & Apoloniusz & Male & 54 & Manager in the newsroom & 17 & 17 \\
\hline & Bruno & Male & 39 & Manager in the newsroom & 12 & 13 \\
\hline & Michał & Male & 35 & Manager in the newsroom & 13 & 13 \\
\hline \multirow{7}{*}{$\begin{array}{l}\text { Creative } \\
\text { staff in the } \\
\text { newsroom }\end{array}$} & Zoja & Female & 70 & $\begin{array}{c}\text { Senior professional in the } \\
\text { newsroom }\end{array}$ & 40 & 40 \\
\hline & Klara & Female & 38 & $\begin{array}{c}\text { Senior professional in the } \\
\text { newsroom }\end{array}$ & 8 & 13 \\
\hline & Stella & Female & 34 & $\begin{array}{c}\text { Senior professional in the } \\
\text { newsroom }\end{array}$ & 10 & 10 \\
\hline & Honorata & Female & 43 & $\begin{array}{c}\text { Senior professional in the } \\
\text { newsroom }\end{array}$ & 11 & 11 \\
\hline & Witold & Male & 31 & $\begin{array}{c}\text { Senior professional in the } \\
\text { newsroom }\end{array}$ & 5 & 11 \\
\hline & Witalis & Male & 30 & $\begin{array}{c}\text { Senior professional in the } \\
\text { newsroom }\end{array}$ & 7 & 7 \\
\hline & Nikodem & Male & 36 & $\begin{array}{c}\text { Senior professional in the } \\
\text { newsroom }\end{array}$ & 10 & 10 \\
\hline
\end{tabular}

Source: Own elaboration 